Interview

\title{
NORMAN DAVIES
}

University College London, School of Slavonic and East European Studies, United Kingdom

\section{ANNA ODROWĄŻ-COATES ${ }^{* *}$}

The Maria Grzegorzewska University, Poland

ORCID 0000-0002-2112-8711

\section{INTERVIEW WITH PROFESSOR NORMAN DAVIES}

\author{
Interview conducted by Anna Odrowąż-Coates
}

Anna Odrowąż-Coates (AOC): Professor Davies because this interview is for the 'Society Register' journal, I would like to start with a general question; What is your attitude towards the interdisciplinary approach to historic research? Is it desirable or even possible?

Norman Davies (ND): I heard the word interdisciplinary and it is very much my line, but it is something more of an aspiration than an easy task. Generally speaking, the setting is thin on modern historians, who ultra-specialize and either they specialize in a very short period of time on a very limited subject and use very limited methods. These days when data information is readily available, well... there is mountains of it. What is needed is not specialized approaches, but approaches which join together different perspectives. Oddly enough it is these simple general histories that don't get written.

\footnotetext{
* Professor Norman Davies CMG, FBA, FLSW, FRSL, FRHistS, Honorary Fellow of St. Antony's College, University of Oxford; Professor Emeritus of UCL-SSEES, an honorary fellow of Clare Hall, Cambridge. Until 2012, he was UNESCO Professor at the Jagiellonian University, Krakow. He specializes in history of Europe, with large volume of works dedicated to Poland. http://normandavies.com/?lang=en ** Corresponding author: The Maria Grzegorzewska University, Social Pedagogy Department, Szczęśliwicka 40, 02-353 Warszawa, Poland.

E-mail: acoates@aps.edu.pl
} 
(AOC): How would you define the place of history in relation to social sciences in general?

Well, history is ought to be the brother or the uncle of social sciences. Unfortunately, the social sciences have developed methods and in particular a language of their own, which is unintelligible to ordinary people

I listened to a lecture recently, in Oxford, by a very distinguished political scientist about the state of Poland and I couldn't understand a single word. Not because the words were in a foreign language. Political scientists think that they can invent terms to suit their ideas rather than fitting their ideas to established language and the result is total unintelligibility.

My view on this subject is rather dim. History and the social sciences don't in practice go together as they should do, because of the completely different traditions of the two subjects.

(AOC): And are you familiar with the term 'public history'?

'Public history'? This is a very good example of people reinventing the wheel. The term 'public history' doesn't mean that historians haven't been doing this sort of thing for centuries. It is old hat. I have done a lot of that sort of history and I can't see any reason to invent a term for it. I know this is a trend. Somehow people want to glorify banalities by fancy terms, but it isn't a real subject, I don't think.

(AOC): In your view how should we preserve the memory of the second world war?

The memory should be preserved by all methods possible. There isn't one single perspective on the war, there isn't one single way of exploring the war. It is very complicated, it involved millions of people and all sorts of ideas and actions and suffering and so on. So, I as you know try to write about history of the second world war, which was quite successful, it's aim was to be comprehensive in the way that I just mentioned, to try and to explore the events of the second world war from many different angles and many different points of view. An inclusive view of the war. Many dozens of leading historians are trying to do the same thing. None of us seem to satisfy the 
demand for knowledge on that subject. The demand is insatiable and nobody seems to be satisfied by our efforts.

(AOC): Professor Davies could please tell our readers why did you decide to focus on the role and the route taken by Polish soldiers in the second world war, why not British, German or American?

Well, the Anders story is not important because it was Polish, it is important because it was absolutely amazing feat, which had never been properly described, not even by Polish historians. Why did I chose to do it? Because nobody else had done it. I have been interested in that subject for 50 years at least. I have some neighbours here in Oxford, who were soldiers in the Anders Army, so I heard of it very early and I was always waiting for somebody to write a decent book and when it didn't happen, I had to write the book myself and I am quite happy with what happened.

(AOC): We are very happy here in Poland, because you seem to promote Poland. A lot of your writings: God's Playground, Heart of Europe and recently Trail of Hope, amongst them.

Oh no, I do not know about that, but the Polish historians you see... They love extremes. They write about for example the deportations to Siberia and Kazakhstan 1940-41, extensively, which is the extreme dark side of the story and they write about Monte Cassino, as though it was just one battle that they fought, which is the very positive side to the story, but they miss out all the bits in between or they don't bring it together into one story and that's what my book did. It started right at the beginning in Russia and it went all the way round the trail until it comes to an end in England in 1946 and 47.

There is one thing that I would like to say in case if you haven't already noticed. One reason that I was keen to write about Anders Army was because Anders had a definition of "Polishness", which is very different from the one that prevails today. General Anders, who was of German origin and wasn't a Catholic, at least he accepted Catholicism in Uzbekistan for political reasons, but he was from a German protestant family, which was Polonized. He had a view like Pilsudski, that Polish citizens of any ethnic background - Jews, Ukrainians, Tatars, Belarusians, Lithuanians, as well 
as ethnic Poles, if you are a Polish citizen you are a Polish and Anders had a great battle to include all Polish citizens in his army. He absolutely rejected the idea of this 'Polak - Katolik' (Polish - Catholic) and this is mentioned in the book briefly, but this is something you should underline. After the war, in London, Anders was constantly attacked by Polish nationalists (National Democracy - 'Endecy'), who wrote all the time: "General Anders is not a Pole" and he took them to court. He took them to an English court and he won his case and these critics were fined for libel, which means a great deal, because modern Poles, unfortunately think of Polishness as being confined to Polish speaking Catholics (Polak - Katolik) and it's not Pilsudski's line it's not Ander's line and it's not my line. There was a big struggle in the USSR when the army was being recruited and the NKVD tried to insist that only ethnic Poles joined the army. Whereas, Anders was adamant that every Polish citizen, irrespectively of whether he could speak Polish or if he was a Catholic or whatever his ethnic background, his language, his political affiliations, everybody qualified to join the army, and he insisted. There was a large number of Jews and one of the big myths, which is quite false, is that Anders wasn't allowing Jews to join the army. When the army gets to Palestine about 3000 Jewish soldiers were allowed to desert. So where did they come from? They'd all have been accepted - including Menachem Begin. Menachem Begin who was a corporal in Anders army, wrote in his memoirs that the anti-Semitic Polish army wouldn't accept Jews, and he himself was accepted. It's just complete tripe. You meet this tripe in many, many books and it is just false. This was one of my reasons for writing this book, to show what honourable view Anders have had of ethnic relations.

One story, which might shock you....

Did you know that the Waffen SS Galician was recruited in Poland? No? nobody told you that. They started to be recruited in Krosno, Sanok, and those places, West of the war-time boundary with the Soviet Union. Then they were increased when the Germans moved to Lwów (Lvov) and into Western Ukraine. All of these Waffen SS soldiers were actually Polish citizens and at the end of the war they fled from the Red Army to Italy, and who did they meet in Italy? You tell me? Who did they meet?, Anders.

Anders saved their lives. The Soviet authorities demanded that they be deported to Soviet Union, were they would undoubtedly be killed. Anders insisted that these are 
Polish citizens, therefore they should be judged by a Polish court martial. He refused to hand them over to the British, because the British would have handed them over to the Russians. What happened to them? Anders took them to England and their headquarters is now in Holland Park in London where there is a nice statue of Saint Volodymir the Great.

(AOC): No I certainly was not aware of that. My next question is what was the inspiration to collect family treasures from around the world, connected to the route that Polish soldiers took to join Ander's Army?

Ah well... One of the reasons I was unavailable was that I had to deliver my autobiography on Friday to the publishers in Cracow (Kraków), it's 1000 pages long and one of the last pages I was writing was about it. I thought about writing about Anders for decades but didn't do it because I was so busy, but when we were in New Zealand, my wife and I called on a lady called Pani Czesława Panek, who had been a small child in Russia during the war and she kept an amazing little diary. Especially of how each of her siblings died. Her mother died, her father died, her brothers died, one of her sisters died and so on and she had this little authentic diary of her horrible life and this is what I think fired me to say 'let's collect as many of these eye witness accounts as we can and illustrate each of the stages of the trail by eye witness accounts rather than by my own description, so that is where that came from.

(AOC): When you took the journey, following the footsteps of WWII heroes, did you experience the effects of emotional transgression - I mean between here and now and the war situation - Did you imagine at any point what it would have been like if you had taken this same route during the war?

Oh of course. It is heart rending every step of the way. For example we went to Pahlavi, which is the port on the Caspian sea - where the ships came from Krasnovodsk in Russia and left the passengers - soldiers and civilians literally on the beach, where thousands of them died. They were too weak to crawl up the beach. There is a little cemetery in Pahlavi, which is filled with hundreds of graves of children, who died mainly from malnutrition and typhus. Oddly enough, a lot of those children and those people, coming out of Russia died after their first meal, because their stomachs were unable to digest food. They had no food for months. When you pack your stomach 
with food it kills you. I don't think there is anyone who would fail to burst into tears at those stories. Can you imagine, they were at the beach in Pahlavi, there were Iranian ice-cream sellers, giving ice cream to these little children, who hadn't seen anything like that for months or years and the ice creams were too difficult for them to eat.

(AOC): Yes, this makes me feel very humbled... I really don't know what to say.... It must have been very hard, just to learn about this, so would you say that you were an outside observer in your research situations or did you feel emotional impact, which would pull you into the stories and places you visited? Was there a pre-set and maintained researcher's position or did your position evolve or change in any way during the study?

Well I am an outsider in time and space. I didn't go along the Anders trail - I never experienced it directly. So I am only a tiny bit engaged but I heard these heart rending, heroic stories from the neighbours of ours. Our neighbour here walked for several thousand kilometres from Uzbekistan to Northern Kazakhstan and back to save his family. He'd already travelled from Arctic Ocean for around $5000 \mathrm{~km}$ arriving in Uzbekistan, heard that his family was in Kazakhstan and he went there. He had no money - he walked to Kazakhstan and back with his family in order to save them. It is absolute heroism. He, his wife and his son and his mother in law, they all survived, but that was quite rare. Huge numbers of Poles, meaning Polish citizens died, but more Polish soldiers died in Soviet Union that died at Monte Cassino.

(AOC): So, given that there was so much material to work with, how difficult was it to decide which stories to choose from and which ones to omit. What criteria did you use for selection?

That was very difficult. I had several hundred memoirs - either printed or online or manuscripts like the one from the lady in New Zealand. I chose them according to time and space. The book had 20 chapters, so I needed at least half a dozen memoirs to illustrate each of the chapters, which makes it 120. I think that there are over 200 in the book on the whole. But I had to find - you know - there are too many memoirs about Siberia, too few about Iraq, or Palestine, or Egypt, so I had to search for the missing pieces of the jigsaw which I succeeded in doing I found more than one memoir for every stage of the journey. 
(AOC): If you were to do it again, is there anything that you would do differently or change in the book Szlak Nadziei?

Oh yes, I would change the cover. I was very unhappy about the cover, but this is the trouble with publishers that they want to sell books and they know that the Polish public will buy any book with a picture of Monte Cassino on the front. I begged them not to put that picture of Monte Cassino on the cover because the book of course includes Mote Cassino, but there are hundreds of books about Monte Cassino and my book was different, it was about soldiers and civilians and the long journey that they made and it wasn't just about this one battle and it wasn't even the most important battle that the Second Corp fought. But of course the author is ignored by the marketing department, they want to sell books so... despite my fervent requests they put that cover on, which I regret to this day because it gives a wrong impression... Authors are not in charge of book production.

(AOC): Would you say that WWII is a closed subject now or is still open to research and interpretation?

There are lots of things that need to be explored, but I think that the main need is to reinterpret the framework of the war. Most people in the West, especially in America, think that the war was between the cowboys in the white hats and the baddies in the black hats. They can't understand that the war in Europe was mainly between two totalitarian states, between Hitler and Stalin. Both of whom were murderers, tyrants, and because Stalin fought on the ally side, it didn't make him a democrat or a nice man, or a friendly regime. Stalin killed more people than Hitler did, and yet, especially in the West, they have this dialectical view of good vs. evil and we are the goodies and anybody who fights against the baddies (i.e. Hitler) is ok. Of course, in Poland it's known better than anywhere else that both of the totalitarian powers were criminal, murderous regimes and you cannot talk about WWII in terms of a good side and a bad side. It was more complicated than that and of course, the winner in Europe was the Red Army. The Red Army made a bigger military contribution than anybody and lost huge numbers of men in the process, but that doesn't mean that they were liberating people. They liberated some and made millions of others captives. 
(AOC): Thank you for these insightful comments on the second world war complexity and now I would like to ask you a lighter question - For me as a Polish person it is very positive that when you refer to Poland you situate Poland in Central Europe, please would you say a few words why?

Why Central Europe today? These geographical terms have got geographical meaning, namely Norway is in the geographical North, Italy is in the geographical South, Russia and Ukraine are in the geographical East and so on. But they also have relative meanings. When during the cold war Europe was divided into two, with the iron curtain down in the middle. There was no central Europe except in a geographical sense. You were either in the West or you were in the East, and Poland found itself in the East. Since the end of the cold war the divisions prior to 1989 now disappeared and we are back to groupings, which are more concerned with relative position rather than absolute geographical locations. We now have a western Europe, obviously Spain, France, Britain are in western Europe and we have eastern Europe which goes down to Romania, Bulgaria and there is this land in the middle, of which Poland is part, some call it east-central Europe, which does not apply to our present situation. Poland is in the central area between the established western countries and the obviously eastern countries.

(AOC): Thank you for this profound explanation Professor Davies and thank you for finding time to give this exclusive interview to the Society Register journal. I am sure your words will inspire further debates and enquiries into WWII, the Anders Army and into relation between history and social sciences. 